\title{
Social Interaction Ability and The Bullying Behaviors among Adolescents : a correlational study
}

\author{
Yoyok Bekti Prasetyo ${ }_{\text {ABCDEFG }}$, NurLailatul Masruroh ${ }_{\text {ABCDEFG }}$, Rakhmad Rosadi ${ }_{\text {ABCDEFG }}^{1}$ Muliani Septia \\ $\operatorname{Rini}^{1}{ }_{\text {ABCDEFG }}$
}

${ }^{1}$ University of Muhammadiyah Malang, Physiotherapy Departement, Health Science Faculty

\begin{abstract}
Background: Bullying is an aggressive behaviors that is done deliberately and happened repeatedly to attack the weak victim, bullying is influenced by factors of ability in social interaction. Low ability in the social interaction will make adolescents turn into an aggressive action for addressing their social problems. The impacts of bullying behaviors are as follows: rejection of peers, deviant behavior, delinquency, crime action, psychological disorders, and depression. Methods: The study design used in this study is observasional with cross sectional approach. This study was conducted on 50 respondents in SMK X Malang. Data analysis was performed with the Spearman rank test. Results: Adolescents whose low ability of social interaction were found higher compared to those whose high and moderate ability. There is a relationship between the ability of social interaction and bullying behavior among adolescent. Conclusions: The ability of adolescent in the social interaction becomes an important factor to be taken to suppress the bullying behavior among adolescents.
\end{abstract}

Key words: Social Interaction, Bullying Behaviors, Adolescents

\section{Background}

Ability in the social interaction could helps teenagers to conform to the standards of community expectations norms prevailing around him [1], because when teenagers can not conform to the norms surrounding, they will turn into somethings' bad and tend to have behavioral disorders and consequently they will also do somethings that can harm themself or others [2]. Furthermore, adolecents who are have low ability in the social interaction tend to show prejudice hostility, when they faced social ambiguous stimulus and they often interpret it as a sign of hostility to deal with aggressive action [3]. The aggressive action that now becomes as a problem in adolescents that occur in school's environment is called as bullying. As its impact, they are often rejected by their parents, peers and environment around [4].

Moreover, bullying is also defined as an aggressive behavior that is intentional happened repeatedly to attack a target or victims who are weak, insulted easily and could not defend themselves [5]. Factors of bullying according to the National Association of School Psychologists (2012) are consist of family, neighborhood, school and individual (groups, social interaction skills, popularity, attitude, gender, age, intellectual, depression).

[6] stated that high school students had bullying intimidation, and the detail of the data are as follows : $7.4 \%$ of students were bullied online, $5 \%$ of high school students reported have been threatened, and 6,6\% have been physically intimidated. [5] said that the rate of violence was $67.9 \%$ in Senior High School, and $66.1 \%$ in Junior High School. It is important to note, the Violence which have been done among students stood at $41.2 \%$ for Junior High Schools and $43.7 \%$ for the Senior High School. It has been knew that the highest category of psychological violence was excommunication, and the second rank is occupied verbal violence (mock) and physical violence (hitting).

The impact of bullying especially for the victim according to a study that conducted by the National Youth Violence Prevention Resource Center Sanders [7] showed that bullying can make teens will feel anxious and frightened, it also affecting concentration in learning and lead them to avoid school. Accordingly, If it continues in the long time, it will influence the self-esteem of students, increasing social isolation, raises withdraws behavior and also makes teenagers are vulnerable to stress and depression, and insecurity feelings. Meanwhile, the bullying performer tends to show an over sense of confidence and high self-esteem as well, they tend to be aggressive and show the behavior that pro-violence. They are the typically rampart, irritable, impulsive and low tolerance of others. The bullying performers tend to have a strong need to dominate others and less empathy to the victims.

In regards to the importance of the ability in the social interaction on bullying behavior in students, especially in adolescents in order to reduce the incidence of bullying behavior, it is necessary to invent studies on the association's ability in the 
social interaction with the bullying behavior on adolescent. The purpose of this study was to determine the relationship between the ability in the social interaction factor and bullying.

\section{Method}

This study used cross sectional design. The population were the students of SMK X Malang, while the samples were 50 adolecents. The independent variable was the ability in the social interaction which consists of 6 domain of social, it measured with SSI (social skills inventory) suggested by [8] the 6 social domain are Emotional Expressivity, Emotional sensitivity, Emotional Control, Social Exspressivity, Social Sensitivity and Social Control. SSI is a Likert scale questionnaire consists of 30 items of statements. Next, the dependent Variable was bullying which means the Aggressive Behaviour such as physical violence, verbal and non-verbal violence that a person / group of people to another individual who is weak. The questioner covered 11 items of statement.

The research findings showed that the low ability of students in social interaction reached 29 (58\%), while the moderate ability was $15(30 \%)$ and the high ability in social interaction was

$6(12 \%)$. The low ability in social interaction was concluded if the score $<75$, and it is moderate if the score of 75-105, and the high ability for the score $>$ 105.

Table.1 The Social Interaction ability of students in SMK X, November 2014

\begin{tabular}{lllll}
\hline \multirow{2}{*}{ No } & \multirow{3}{*}{ Domain } & \multicolumn{3}{l}{ The Social Interaction ability } \\
\cline { 3 - 5 } & & Low & Moderate & High \\
& & $\mathbf{f} / \%$ & $\mathbf{f} \%$ & $\mathbf{f} \% \%$ \\
\hline 1 & Emotional Sensitivity & $19 / 38 \%$ & $26 / 52 \%$ & $5 / 10 \%$ \\
2 & Emotional Exspressivity & $28 / 56 \%$ & $18 / 36 \%$ & $4 / 8 \%$ \\
3 & Emotional Control & $16 / 32 \%$ & $27 / 54 \%$ & $7 / 14 \%$ \\
4 & Social Exspressivity & $23 / 46 \%$ & $24 / 48 \%$ & $3 / 2 \%$ \\
5 & Social Sensitivity & $15 / 30 \%$ & $34 / 68 \%$ & $1 / 2 \%$ \\
6 & Social Control & $28 / 56 \%$ & $16 / 32 \%$ & $6 / 12 \%$ \\
\hline
\end{tabular}

Based on Table 1 it can be seen that both of Emotional Expressivity and Social Control gained the highest percentages with $56 \%$, and both of these had the low ability of social interaction.

\section{The Discription of bullying behaviors among ad-} olescents in SMK X Malang

Table 2. Bullying behaviors among students in SMK X Malang, November 2014

\begin{tabular}{llll}
\hline No & The score of bullying behavior & Frequency & Percentage \\
\hline 1 & Low & 9 & $18 \%$ \\
2 & Moderate & 38 & $76 \%$ \\
3 & High & 3 & $6 \%$ \\
& Total & 50 & $100 \%$ \\
\hline
\end{tabular}

Based on the Table 2, it shows that the highest number of respondents who have bullying behavior was 38 (76\%). The types of bullying that more dominant among adolescents in SMK X Malang is a bullying direct physical contact. The second position of the type of bullying is directly contact verbal bullying. Next, the third position is nonverbal directly bullying, and the fourth rank is indirect nonverbal bullying.

\section{The Relationship between the Ability of Social Interaction and Bullying Behavior among Ado- lescents}

Table 3. Spearman rank Tests Results Analysis: The relationship between the Ability of Social Interaction and Bullying Behavior among Adolescents in SMK X Malang

\begin{tabular}{|l|l|l|l|l|l|}
\hline Variable & $\mathrm{R}_{\text {count }}$ & $\begin{array}{l}\text { Signifi- } \\
\text { cant }\end{array}$ & $\mathrm{r}_{\text {table }}$ & $\alpha$ & $\begin{array}{l}\text { Conc- } \\
\text { lusion }\end{array}$ \\
\hline $\begin{array}{l}\text { The factor of } \\
\text { ability in the so- } \\
\text { cial interaction } \\
\text { with bullying } \\
\text { behavior }\end{array}$ & 0,566 & 0,001 & 0,279 & 0,05 & $\begin{array}{l}\mathrm{H}_{1} \text { ac- } \\
\text { cepted }\end{array}$ \\
\hline
\end{tabular}

Based on the analysis in Table 3 above, it can be explained that the probability value (Sig.) $<$ A. Where it can be concluded that $\mathrm{Hi}$ is accepted, it means that there is a relationship between Ability of Social Interaction and the Bullying Behavior. The amount of 0.566 correlation shows that the level of relationship between the two variables is moderate.

\section{Discussion}

Basically there is no theory that explains precisely that men are more likely have lower ability in the social interaction than women. It has been proved from this study that the ability of social interaction of man is much lower than women. Based on the characteristics of social life between men and women, Rahayu (2008) said that women are more socially sensitive, however, men are more selfish (selfish), so that all their activities and life are always linked to their wide-range of projects and materials from his work.

Emotional expressivity is generally refers to sending nonverbal communication skills, it reflects the individual's ability to express emotions spontaneously and accurately, feeling emotional states and the ability to express attitude and nonverbal cues of interpersonal orientation [9] Whereas Social Control refers to skills in self-presentation on 
an environmental social. Individuals with high social control will act skillfully capable of playing a variety of social roles and can easily socialize in the discussion. Individuals who have a high social control are smarter and wiser. Therefore, they can adjust personal behavior to conform to certain social situations [10].

The important of having ability in the social interaction for adolescents according to [11]:

1) Development of Personality and Identity; 2) Develop the Job Skills, Productivity and Career Success. 3) Improving the quality of life is another positive result of the ability in the social interaction because each individual requires a good relationship, close and intimate with another individual, 4) Improve Physical Health, Good relationships and mutual support will affect the physical health. Research shows that high-quality relationships associated with long life and can be recovered quickly from illness, 5) Improve Psychological Health. A research shows that

a strong healthy psychology is influenced by positive relationships and the support from others.

Ability in the social interaction should be mastered by adolescents as a part of the development tasks so they are adaptable with the norms of surroundings [12] because when teens have the ability in the social interaction inept teenagers will have behavioral disorders that can harm themselves and others (Lohey 2007) than it makes teenagers less able to establish effective interaction with the environment and choosing aggressive actions as a coping strategy.

\section{The Discription of bullying behavior among ado- lescents in SMK X Malang}

[13] identify the characteristics of the physical and mental characteristics of bullies or bully. Bullies is the aggressor, provocateurs and initiator of bullying situations. In general, Perpetrators are students who are physically large and strong, but not infrequently also he is small or medium but has a strong psychological dominance among his friends due to factors social status or position, while the characteristics of the victims of bullying based on [14] are: The new comer in the neighborhood, the youngest or smallest children in schools, and those who have traumatic experiences are often avoiding something that scarred them, childen who are look obedient sometimes to covering their anxiety, lack of confidence, or children who does something because of afraid to be hated or want to please others, children whose behavior is considered disturbing others, those who do not want to fight or tend to show caving, children who are shy and hiding his feelings, and children who are reticent or unwilling to attract people's attention.

Bullying among adolescents and in the school environment had to get his attention because of the impact of bullying on victims and perpetrators. the impact of bullying to the victims according to a study conducted by the National Youth Violence Prevention resourse Center [7] shows that bullying can make teens feel anxious and frightened, affecting concentration in school and lead them to avoid school. If the bullying continues in the long term, can affect self-esteem of students, increasing social isolation, raises withdraws behaviors, make adolescents vulnerable to stress and depresion, and also insecurity feelings. In more extreme cases, bullying can lead teens to do reckless, even kill, or commit suicide (commited suicide). The impact to the perpetrator is they will assume that they have a power of the situation around. If it continues without any interventions, next bullying can lead to the formation of other behaviors such as violence against children and other criminal behavior.

\section{The relationship between the Social Interacting Factor Ability and Bullying Behavior in Adole- scents}

According to Hurlock, most of adolescents are unstable over time as a consequence of the effort of adjustment on new patterns of behavior and new social expectations, teens are required to conform to the norms and expectations that exist in the community, and have a good ability of social interaction. When the ability of social interaction is low, it will lead to the less of capability to establish effective interaction with the environment and it will turn into choosing an aggressive actions as a coping strategy. One aggressive action of adolescents in schools is bullying. An overview of the bullying behavior from this study in SMK X Malang shows in a moderate level with $38(76.00 \%)$, so that it is expected that students in SMK X can improve their ability in the social interaction to be better so the bullying or aggressive actions in schools will not occur.

\section{Conclusion}

The conclusion of this study were: 1) The description of adolescents' ability of social interaction in SMK X Malang shows that the number of 
students who have low ability of social interaction is higher than those with the moderate and the high, 2) The students of SMK X Malang have the low of Emotional Exspressivity and Social Control, 3) The description of bullying behavior among adolescents in SMK X Malang is in the moderate category, 4) There is a correlation between the ability of social interaction with bullying behavior among adolescents in SMK X Malang.

\section{References:}

1. Matson JL \& Ollendick T. Enhancing Children's Social Skill :Assesment and Training. New York : Pergamon Press; 2011.

2. Lohey BB. Psychology an Introduction. New York :McGrow- Hill Company; 2007.

3. Crick HR, Dodge KA. A review and reformulation of social information processing mechanisms in children's : social adjustment psychological.2005; 15(1): 74-101.

4. Patterson GR. A developmental perspective on anti social behavior: American Psychologist.2005; 44.329-335.

5. Sejiwa. Bullying mengatasi kekerasan disekolah dan lingkungan sekitar anak, Jakarta: Grasindo; 2008.

6. Koebler J. Bullying dan Peserta didik. 2011.

7. Sanders. Bullying : Impications For the Classroom. California USA: Elsevier Academic Press; 2005.

8. Riggio RE, Carney DR. Social skills inventory manual (seconded.): Mind Garden.2003.
9. Friedman, Riggio Assesment of basic social skills.Journal of Personality and Social psychology. 2005; 51 (3), 649-660..

10. Loton D. Problem video game playing, selft esteem and social skills. Victoria University.2007.

11. Johnson DW, Johnson FP. Joining Together group Theory and Group Skill. Boston : allyn\& Bacon; 2004.

12. Mu'tadin Z. Kemandirian sebagai kebutuhan psikologi, diundah pada tanggal 25 januari 2012

13. Rigby K. Bullying In Schools and what do about it. Acer Dress: Camberwell Australia; 2007.

14. Coloroso B. Stop bullying (memutuskan rantai kekerasan anak dari prasekolah hingga SMU) Jakarta: PT. Ikrar Mandiri Abadi; 2006.

\section{Correspondence address:}

Yoyok Bekti Prasetyo

University of Muhammadiyah Malang,

Physiotherapy Departement,

Health Science Faculty 